\title{
Serum Zinc, Iron and Urinary Iodine Levels and their Relationship to Other Indices of Malnutrition among Lactating Mothers in Two Agro-Ecological Zones of Rural Ethiopia
}

\author{
Roba KT ${ }^{1,2}$, O’Connor $\mathrm{TP}^{2}$, Belachew $\mathrm{T}^{3}$ and $\mathrm{O}^{\prime}$ Brien $\mathrm{NM}^{\star 2}$ \\ ${ }^{1}$ College of Health \& Medical Science, Haramaya University, Harar, Ethiopia \\ ${ }^{2}$ School of Food and Nutritional Sciences, University College Cork, Cork, Ireland \\ ${ }^{3}$ Department of Population \& Family Health, College of Public Health \& Medical Sciences, Jimma University, Jimma, \\ Ethiopia
}

*Corresponding author: O’Brien NM, School of Food and Nutritional Sciences, University College Cork, Cork, Ireland, Fax: +353 21 4270244, Tel: +353 21 4902884, E-mail: nob@ucc.ie

Citation: Roba KT, O’Connor TP, Belachew T, O’Brien NM (2016) Serum Zinc, Iron and Urinary Iodine Levels and Their Relationship to Other Indices of Malnutrition among Lactating Mothers in Two AgroEcological Zones of Rural Ethiopia. J Nutr Health Sci 3(2): 202. doi: 10.15744/2393-9060.3.202

Received Date: March 15, 2016 Accepted Date: May 24, 2016 Published Date: May 26, 2016

\begin{abstract}
There are limited studies on the magnitude and severity of zinc, iron and iodine deficiency, in addition to inadequate serum ferritin levels and anaemia, among lactating mothers across different agro-ecological zones of rural Ethiopia. A cross-sectional study examining socio-demographic parameters, anthropometry, dietary diversity, household salt usage, urinary iodine and blood tests for zinc, ferritin and anaemia was conducted in 202 mothers among eight rural villages from lowland and midland agro-ecological zones of Ethiopia. Goitre was determined by palpation. The prevalence of low status of serum zinc, ferritin, iron deficiency anaemia (IDA), and total goitre rates among lactating mothers irrespective of their agro-ecological zones were $71.8 \%, 60.4 \%, 10.9 \%$, and $35.2 \%$, respectively. The median urinary iodine was $120 \mu \mathrm{g} / \mathrm{L}$. Low level of serum zinc, iron and IDA was significantly higher in lowland mothers (96.2\%, $89.4 \%$ and $20.2 \%)$ than in midland agro-ecological zone (45.9\%, 29.9\%, and $1.0 \%)$. Prevalence of goitre among lactating mothers was not significantly different across agro-ecological zones. Adequately iodised salt was available in $36.6 \%$ of households. Of the mothers, $37.5 \%$ in lowland were deficient in both biomarkers (zinc and ferritin) while only $2.0 \%$ in midland agro-ecological zone were deficient. None of the lactating mothers were aware of iodine deficiency diseases or the importance of using iodised salt. Haemoglobin levels were significantly correlated with maternal body mass index (BMI), mid-upper arm circumference (MUAC) and dietary diversity. Lactating mothers in rural Ethiopia are at high risk of micronutrient deficiencies. The prevalence of micronutrient deficiencies was significantly influenced by agro-ecological zone.
\end{abstract}

Keywords: Zinc; Ferritin; Iodine; Ethiopia; Lactating mothers

\section{Introduction}

Micronutrient deficiencies are a major public health problem in many developing countries, particularly in infants and pregnant women. In 2011, 116,000 deaths in children under 5 years were attributable to zinc deficiency (1.7\% of mortalities in this group) [1]. Approximately, 2 billion people (over 30\% of world population) are anaemic, many due to iron deficiency [2]. Additionally, about 1.88 billion $(28 \%)$ of the world's population are considered to have insufficient iodine intake and hence are at risk of iodine deficiency, of whom more than 321 million are Africans [3].

Zinc is a micronutrient with diverse physiologic and metabolic functions [4]. It is involved in all the main biochemical pathways and plays multiple roles in cellular proliferation and differentiation. It affects physical growth, immunity, reproductive function and neuro-behavioural development [5]. The amount of zinc required for non-pregnant adult women (19+ years) is 9 mg per day. This amount increases to $11 \mathrm{mg}$ zinc/d in pregnancy and in lactation to $12 \mathrm{mg} / \mathrm{d}$ [6].

Iron deficiency occurs predominantly due to a deficiency of bioavailable dietary iron and/or increased demands such as during childhood, pregnancy and lactation [7]. High demands for iron due to menstrual blood loss, pregnancy, lactation and nutritional deficiencies are the most common causes of iron deficiency anaemia in reproductive-age women [8]. Nutritional requirements during lactation are greater than during pregnancy [9]. The quantity of milk produced by mothers depends very much on the mother's diet [9]. Severely malnourished mothers have reduced lactation performance contributing to increased risk of child mortality [10]. 
Lactating mothers from low-income settings are considered as a nutritionally vulnerable group [11]. Anaemia was estimated to be an underlying factor for $22 \%$ of maternal deaths around the world, of which severe anaemia is a major contributor [12,13]. The few studies conducted among Ethiopian mothers on prevalence of zinc and iron deficiency suggest there is very high level of prevalence. A study conducted in Gondar (Northwest Ethiopia) among pregnant and non-pregnant mothers reported prevalence of low zinc status was $74 \%$ and 55\%, respectively [14]. Similarly, another study evaluating zinc deficiency among pregnant women in rural Sidam, South Ethiopia, reported prevalence of 53\% [15]. According to a study in nine different regions of Ethiopia conducted by Umeta, et al. [16], the prevalence of anaemia, ID and iron deficiency anaemia (IDA) were 30.4, 49.7 and $17.0 \%$, respectively. The single study in Ethiopia documenting the prevalence of low serum ferritin among lactating mothers in a slum of Addis Ababa reported that the prevalence was $22.3 \%$ [17]. Similarly, iodine deficiency in eastern Ethiopia has a prevalence of $82 \%$ among pregnant women [18]. In Ethiopia, goitre rates are reported to range from $34.5 \%$ to $37.0 \%$ among childbearing women [19].

Although low serum level of zinc and iron, and iodine deficiency is increasingly being recognized as a widespread problem in Ethiopia, there are very limited studies on the prevalence and severity of these deficiencies among lactating mothers across different agro-ecological zones in Africa, particularly in Ethiopia. This study was conducted in two agro-ecological zones of rural Ethiopia with the aim of assessing the prevalence and variations of maternal zinc, iron and iodine deficiency across these zones and their relationship to other indices of malnutrition.

\section{Materials and Methods}

\section{Participants and study design}

The study was conducted in the Babile, Enderta and Hintalo Wajirat districts of Ethiopia. These districts were selected due to their proximity to the two Ethiopian universities who were partner institutions in this project funded by Irish Aid. Babile District (Woreda), which is $560 \mathrm{~km}$ away from Addis Ababa in the eastern part of Ethiopia and adjacent to Haramaya University, represented a lowland agro-ecological zone. The altitude of Babile Woreda ranges from 950 to 2000 meters above sea level and data were collected from 1000-1500 meters above sea level. The major agricultural product for consumption is sorghum, and oil seeds and groundnuts are used as cash crops. Hintalo Wajirat and Endreta districts $(683 \mathrm{~km}$ and $773 \mathrm{~km}$ away from Addis Ababa in the Northern part of Ethiopia, respectively and adjacent to Mekelle University) represent midland agro-ecological zones. Data were collected from altitude of greater than 2000 meters above sea level where the majority produce cereals (Teff and barley) and are involved in animal husbandry.

A community based cross sectional study was conducted in four kebeles randomly selected from each geographical area. The study was conducted from January to February 2014 which is the post-harvest season. Data on socio-demographic status, anthropometry and feeding practices were generated. Blood and urine samples were collected from the mothers. Out of the 208 mothers who gave samples of blood for test of ferritin, haemoglobin and zinc, 202 (97\%) samples were analysed, while the remaining samples were discarded due to insufficiency ( 3 samples) and haemolyses (3 samples). Urinary iodine levels and salt iodine concentration were measured and goitre rates were assessed by palpation.

\section{Socio-demographic status and anthropometric measures}

Socio-demographic characteristics of the participants were assessed using a pre-tested questionnaire that included questions on education levels, health services utilization and water and sanitary facilities. Weights of the lactating women were measured to the nearest $0.1 \mathrm{~kg}$ on a battery powered digital scale (Seca 770, Hanover Germany) with a weighing capacity of 0 to $140 \mathrm{~kg}$ and heights were measured to the nearest $0.1 \mathrm{~cm}$ using a wooden height-measuring board with a sliding head bar following standard anthropometric techniques [20]. Mid upper arm circumference (MUAC) was also measured using a non-stretchable MUAC tape (MUAC measuring tape/PAC-50) [20] on the left upper arm of the mothers. To measure weight and height, study subjects removed their shoes, jackets and wore light clothing. To avoid variability among the data collectors, all the anthropometric measurements were taken by two different data collectors and compared. In case of variation among the data collectors, the researcher (the first author) took the measurement again for validation. The Body Mass Index (BMI) [weight $\left./ \mathrm{height}^{2}\left(\mathrm{~kg} / \mathrm{m}^{2}\right)\right]$ was calculated and the threshold of $18.5 \mathrm{~kg} / \mathrm{m}^{2}$ was used to identify underweight women.

\section{Dietary intake assessment}

Dietary intake was assessed by simple questionnaire that allowed all types of foods consumed during each of the 24 previous hours to be noted. Each woman involved in the study was asked to recall all the communal dishes she had eaten in the compound during this period. The recall was randomly made on weekdays or on weekend days, since weekends do not have any special significance with respect to dietary intake in the context of our study. We took care to not include atypical days (local feasts or celebrations) in the recall. The protocol of Women Dietary Diversity Score (WDDS) was standardized by FANTA [21].

\section{Blood collection, serum separation and micronutrient measurements}

Five millilitres of venous blood were collected aseptically in the morning [22] from the antecubital vein of the participants and was aliquoted into tubes without anticoagulants by a trained health professional. Samples of serum were collected in to zinc/metal free vacutainers and gloves were free of talcum powder. A sample was allowed to clot and centrifuged to separate serum. Serum 
was stored frozen at $-20{ }^{\circ} \mathrm{C}$ and transported by plane to the Ethiopian Public Health Institution (EPHI http://www.ephi.gov.et), Addis Ababa. Serum ferritin, which reflects body iron stores, was analysed using an enzyme-linked immunosorbent assay (ELISA) with a fully automated Elecsys 1020 using commercial kits purchased from Boerrhinger Mannheim, Germany by a senior medical technologist. Serum ferritin (SF) levels were defined as: iron deficiency if SF $<15 \mu \mathrm{g} /$ litre as recommended by WHO [23].

A small portion of whole blood from the syringe was used to test haemoglobin level of the mothers immediately on site by using portable HemoCue analyser (HemoCue $\left.{ }^{\oplus} \mathrm{Hb} 301\right)$ which is considered to be a gold standard for field work in resource poor settings [24]. The cut-off point for anaemia was based on WHO (2011) recommendation for non-pregnant mother. The threshold criteria used to determine the severity of anaemia as a mild, moderate or severe public health problem were as follows: prevalence rate of anaemia was mild 5.0-19.9\%, moderate was 20-39.9\% and severe was $>40 \%$, respectively. Level of anaemia was classified as: mild anaemia (Hgb 10-11.9 g/dl), moderate anaemia (Hgb 7-9.9 g/dl) and severe anaemia (Hgb less than $7 \mathrm{~g} / \mathrm{dl})$. Haemoglobin level was adjusted for altitude as follow: altitude of less than 1000 meter above sea level had no adjustment for haemoglobin, for 1000 meter subtract $0.2 \mathrm{~g} / \mathrm{dl}$, from 1000-1500 meter, subtract $0.5 \mathrm{~g} / \mathrm{dl}$, from 1500-2000 meter, subtract $0.8 \mathrm{~g} / \mathrm{dl}$ and 2000 to 2500 subtract $1.3 \mathrm{~g} / \mathrm{dl}$ from haemoglobin reading. Iron deficiency anaemia was defined as serum ferritin less than $15 \mu \mathrm{g} /$ litre and haemoglobin less than $12 \mathrm{~g} / \mathrm{dl}[25]$

For the determination of zinc, frozen sera were shipped to EPHI on dry ice in polystyrene packaging material. The concentration of zinc in serum was determined at the National Food, Medicines, Health Service Administration and Control Authority (FMHACA) laboratory by using Shimadzu Flame Atomic Absorption Spectroscopy (AA 6800 model, Japan). Serum samples (200 $\mu \mathrm{L}$ ) were added to a trace metal-free plastic test tube and diluted by addition of $6 \%$ butanol in 1:5 ratios. Calibration of the Atomic Absorption Spectrophotometer was carried out using a series of standards of zinc, 0, 0.1, 0.2, 0.3 and $0.4 \mathrm{ppm}$ by dilution from stock of 1000 ppm AAS zinc standards. Each series of standards was diluted with $5 \%$ glycerol to equate with viscosity of serum. Zinc concentration was measured using an air-acetylene flame at a wavelength of $213.9 \mathrm{~nm}$ and a slit width of $0.7 \mathrm{~nm}$. The results were calculated from two runs [26,27]. To minimize the risk of contamination, all glassware and plastic tubes used were immersed in $10 \%(\mathrm{v} / \mathrm{v})$ solution of nitric acid for $24 \mathrm{~h}$, washed with distilled water and rinsed with deionized water before use. Because blood samples in this survey were not necessarily obtained fasting but collected in the morning between 8-10 a.m., we used a cut-off value of $66 \square \mathrm{g} / \mathrm{dl}$ for mothers and $65 \square \mathrm{g} / \mathrm{dl}$ for children, as recommended by the International Zinc Nutrition Consultative Group (IZiNCG) [22].

\section{Urinary iodine}

To determine the presence of iodine in the household salt, data collectors asked households to provide a teaspoon of the salt used for cooking on the night prior to data collection. The salt was immediately tested on site for iodine using the iodine rapid test kit (MBI Kits International).

Five to ten millilitres of spot urine samples were collected from all mothers to examine urinary iodine concentration (UIC). Samples were tightly sealed in plastic tubes that were free from iodine or any other chemical to avoid leakage and cross-contaminations with iodine from other sources. The urine samples were kept in a cold box until analyses were performed in duplicate in the iodine laboratory of the EPHI using the method based on the Sandell-Kolthoff reaction [27]. UIC was expressed as the median micrograms of iodine per liter ( $\mu \mathrm{g} / \mathrm{litre}$ ) of urine. Urinary iodine status of the lactating mothers was classified using WHO/ UNICEF/ICCIDD recommended cut-off points for urinary iodine concentration for populations [29]. That is $\geq 100 \square \mathrm{g} /$ litre is categorized as adequate and $<100 \square \mathrm{g} /$ litre insufficient.

\section{Goitre rates}

All mothers were clinically examined by trained nurses for goitre using palpation of the thyroid. Five day practical training was given on how to palpate neck for goitre and demonstration and evaluation was given during pretesting of the tools. Classification of goitre rate was made as recommended by WHO/UNICEF/ICCIDD [30].

\section{Variables}

Dependent variables were micronutrients and biomarkers of micronutrient status (serum zinc, ferritin, iron deficiency anaemia, urinary iodine) among lactating mothers. The independent variables were the socio-demographic and economic status, health status of mothers, water, sanitation, health services utilization and cultural/social characteristics related to feeding style of the mother. Nutritional knowledge of mother, WDDS and meal frequency, and health seeking behavior of the family was also assessed.

\section{Data processing and analysis}

The data were double entered by separate data clerks into EPI Data version 3.1. Data cleaning and editing were undertaken before analysis. Data were checked for normality by using the Kolomogrov-Smirnov test. Data were transferred to SPSS (v 16.0) statistical packages and Stata (v.11) for analysis. Descriptive statistics were used to show the magnitude of each variable. Cross tabulations and linear regression were used to see the difference across the agro-ecological regions and associations of different variables. For WDDS, BMI, anthropometric data, haemoglobin and serum ferritin levels, mean and standard deviation were analysed. Multiple binary and linear logistic regressions were applied to control for confounding after testing binary linear regression. 


\section{Ethical consideration}

This study was conducted according to the guidelines laid down in the Declaration of Helsinki and all procedures involving human subjects/patients were approved by University College Cork, Ireland and Haramaya University College of Health and Medical Sciences Institution, Ethiopia, Research Ethics Review Committees. Subsequently, the final approval of the protocol was granted by the Ethiopian National Ministry of Science and Technology Ethical Review Committee. Informed consent was obtained from the mothers and they were informed that they had the right to refuse or exit from the study at any time and refusing to participate in the study would not have any negative implications for them. Women who were found to be undernourished during assessment were referred to the nearest health institution for health care services.

\section{Results}

The majority 137 (67.8\%) of the mothers were illiterate. Health service utilization was low as 138 (68.3\%) of the mothers reported that they gave birth at home. The majority $145(71.8 \%)$ of the mothers wash their hands after toilet but only 113 (55.9\%) households have toilet facility (Table 1).

Concerning feeding practices, $56.9 \%$ of the households never consumed meat and $47 \%$ never consumed egg at least one time in the previous month. The majority (60.9\%) of mothers reported that they drink coffee or tea more than four times in a week, and $86.6 \%$ drank coffee the day preceding the survey. Only $27.7 \%$ drink milk or milk with coffee. About $78.7 \%$ of the households reported that they cook salt with food and $18.3 \%$ of households reported washing their salt before use as majority of the households in rural Ethiopia use crystal salt (Table 1).

\begin{tabular}{|c|c|c|c|c|c|}
\hline Variables & Category & Total n (\%) & $\begin{array}{l}\text { Lowland } \\
\text { n }(\%)\end{array}$ & $\begin{array}{l}\text { Midland } \\
\text { n (\%) }\end{array}$ & $P$-value \\
\hline Age (y) & $\begin{array}{l}15-24 \\
25-34 \\
35-49\end{array}$ & $\begin{array}{c}48(23.8) \\
114(56.4) \\
40(19.8)\end{array}$ & $\begin{array}{l}22(21.2) \\
63(60.6) \\
19(18.2)\end{array}$ & $\begin{array}{l}26(26.5) \\
51(52.0) \\
21(21.5)\end{array}$ & $\begin{array}{l}1.00 \\
0.52 \\
0.93\end{array}$ \\
\hline Education & $\begin{array}{c}\text { Illiterate } \\
\text { Attend school }\end{array}$ & $\begin{array}{l}137(67.8) \\
65(32.2)\end{array}$ & $\begin{array}{l}78(75.0) \\
29(25.0)\end{array}$ & $\begin{array}{l}59(60.2) \\
39(39.8)\end{array}$ & 0.19 \\
\hline Parity & $\begin{array}{c}3 \text { and below } \\
>=4\end{array}$ & $\begin{array}{c}71(35.1) \\
131(64.9)\end{array}$ & $\begin{array}{l}38(36.5) \\
66(63.5)\end{array}$ & $\begin{array}{l}33(33.7) \\
65(66.3)\end{array}$ & 0.80 \\
\hline $\begin{array}{l}\text { Took deworming tablets during } \\
\text { pregnancy }\end{array}$ & $\begin{array}{l}\text { No } \\
\text { Yes }\end{array}$ & $\begin{array}{l}132(65.3) \\
70(34.7)\end{array}$ & $\begin{array}{l}65(62.3) \\
39(37.7)\end{array}$ & $\begin{array}{l}67(68.4) \\
31(31.6)\end{array}$ & 0.60 \\
\hline Family size & $\begin{array}{l}1-5 \\
>5\end{array}$ & $\begin{array}{l}100(49.5) \\
102(50.5)\end{array}$ & $\begin{array}{l}54(51.9) \\
50(48.1)\end{array}$ & $\begin{array}{l}48(46.9) \\
52(53.1)\end{array}$ & 0.80 \\
\hline Number of children $<5 \mathrm{y}$ & $\begin{array}{c}1 \text { child } \\
2 \text { children } \\
3 \text { children }\end{array}$ & $\begin{array}{c}79(39.1) \\
110(54.5) \\
13(6.4)\end{array}$ & $\begin{array}{l}30(28.8) \\
61(58.7) \\
13(12.5)\end{array}$ & $\begin{array}{c}49(50) \\
49(50) \\
0\end{array}$ & $\begin{array}{l}1.00 \\
0.19 \\
-\end{array}$ \\
\hline Household with toilet & $\begin{array}{l}\text { Yes } \\
\text { No }\end{array}$ & $\begin{array}{l}113(55.9) \\
89(44.1)\end{array}$ & $\begin{array}{l}52(50.0) \\
52(50.0)\end{array}$ & $\begin{array}{l}61(62.2) \\
37(37.8)\end{array}$ & 0.30 \\
\hline Hand washing after toilet & $\begin{array}{l}\text { Yes } \\
\text { No }\end{array}$ & $\begin{array}{l}145(71.8) \\
57(28.2)\end{array}$ & $\begin{array}{l}76(73.1) \\
28(26.9)\end{array}$ & $\begin{array}{l}69(70.4) \\
29(29.6)\end{array}$ & $\begin{array}{l}0.80 \\
0.70\end{array}$ \\
\hline Birth interval & $\begin{array}{c}\text { First birth } \\
1-2 y \\
>2 y\end{array}$ & $\begin{array}{l}27(13.4) \\
89(44.1) \\
86(42.5)\end{array}$ & $\begin{array}{l}11(10.6) \\
59(56.7) \\
34(32.7)\end{array}$ & $\begin{array}{l}16(16.3) \\
30(30.6) \\
52(53.1)\end{array}$ & $\begin{array}{l}1.00 \\
0.14 \\
0.96\end{array}$ \\
\hline Attend antenatal care & $\begin{array}{l}\text { No } \\
\text { Yes }\end{array}$ & $\begin{array}{c}32(15.8) \\
170(84.2)\end{array}$ & $\begin{array}{l}22(21.2) \\
82(78.8)\end{array}$ & $\begin{array}{l}10(10.2) \\
88(89.8)\end{array}$ & 0.20 \\
\hline Place of delivery of index child & $\begin{array}{c}\text { Home } \\
\text { Health institution }\end{array}$ & $\begin{array}{c}138(68.3) \\
64(31.7)\end{array}$ & $\begin{array}{l}86(82.7) \\
18(17.3)\end{array}$ & $\begin{array}{l}52(53.1) \\
46(46.9)\end{array}$ & 0.01 \\
\hline Meat consumption in a month & $\begin{array}{l}\text { Never } \\
1-2 \text { times }\end{array}$ & $\begin{array}{l}115(56.9) \\
87(43.1)\end{array}$ & $\begin{array}{l}84(80.8) \\
20(19.2)\end{array}$ & $\begin{array}{l}31(31.6) \\
67(68.4)\end{array}$ & 0.00 \\
\hline Egg consumption in a month & $\begin{array}{c}\text { Never } \\
\text { 1-2 times } \\
\text { 3-6 times }\end{array}$ & $\begin{array}{l}95(47.0) \\
67(33.2) \\
40(19.8)\end{array}$ & $\begin{array}{l}73(70.2) \\
13(12.5) \\
18(17.3)\end{array}$ & $\begin{array}{l}22(22.4) \\
54(55.2) \\
22(22.4)\end{array}$ & $\begin{array}{c}<.001 \\
0.23 \\
1.00\end{array}$ \\
\hline Eat legumes yesterday & $\begin{array}{l}\text { No } \\
\text { Yes }\end{array}$ & $\begin{array}{c}60(29.7) \\
142(70.3)\end{array}$ & $\begin{array}{l}59(56.7) \\
45(43.3)\end{array}$ & $\begin{array}{c}1(1) \\
97(99)\end{array}$ & $<0.001$ \\
\hline $\begin{array}{c}\text { Consumption of tea/ coffee in } \\
\text { a week }\end{array}$ & $\begin{array}{l}<4 \text { times } \\
>4 \text { times }\end{array}$ & $\begin{array}{c}79(39.1) \\
123(60.9)\end{array}$ & $\begin{array}{l}25(24.0) \\
79(76.0)\end{array}$ & $\begin{array}{l}54(55.1) \\
44(44.9)\end{array}$ & 0.009 \\
\hline Drink coffee yesterday & $\begin{array}{l}\text { No } \\
\text { Yes }\end{array}$ & $\begin{array}{c}27(13.4) \\
175(86.6)\end{array}$ & $\begin{array}{l}18(17.3) \\
86(82.7)\end{array}$ & $\begin{array}{c}9(9.2) \\
89(90.8)\end{array}$ & 0.30 \\
\hline Drink milk yesterday & $\begin{array}{l}\text { No } \\
\text { Yes }\end{array}$ & $\begin{array}{c}146(72.3) \\
56(27.7)\end{array}$ & $\begin{array}{l}51(49.0) \\
53(51.0)\end{array}$ & $\begin{array}{c}95(96.9) \\
3(3.1)\end{array}$ & $<0.001$ \\
\hline
\end{tabular}




\begin{tabular}{|c|c|c|c|c|c|}
\hline Variables & Category & Total n (\%) & $\begin{array}{c}\text { Lowland } \\
\mathbf{n}(\%)\end{array}$ & $\begin{array}{c}\text { Midland } \\
\mathbf{n}(\%)\end{array}$ & $\boldsymbol{P}_{\text {-value }}$ \\
\hline \multirow{2}{*}{ Wash salt before use } & No & $165(81.7)$ & $87(83.7)$ & $78(79.6)$ & 0.66 \\
& Yes & $37(18.3)$ & $17(16.3)$ & $20(20.4)$ & \\
\hline \multirow{2}{*}{ Practice of using salt } & Add after cooking & $43(21.3)$ & $9(8.7)$ & $34(34.7)$ & 0.01 \\
& Cook with food & $159(78.7)$ & $95(91.3)$ & $64(65.3)$ & \\
\hline
\end{tabular}

${ }^{*}$ Babile District (Woreda) which is $560 \mathrm{~km}$ away from Addis Ababa in the eastern part of Ethiopia is representing a lowland agroecological zone. ${ }^{* *}$ Hintalo Wajirat and Endreta districts are $683 \mathrm{~km}$ and $773 \mathrm{~km}$ away from Addis Ababa in the northern part of Ethiopia, respectively and represent midland agro-ecological zones

Table 1: Distribution of selected socio-demographic and maternal characteristics of lactating mothers in two agro-ecological zones of rural Ethiopia $(\mathrm{N}=202)$

\section{Comparison of maternal characteristic between the two agro-ecological zones}

Among 202 participants included in the survey, mean and standard deviation of age were $28.5 \pm 5.9$ years. Comparing maternal characteristics of lowland and midland, midland had significantly $(\mathrm{p}<0.05)$ higher rate of focused antenatal care, haemoglobin, serum zinc, and serum ferritin concentrations than their lowland counterparts, while the latter had a statistically significant $(\mathrm{p}<0.05)$ higher number of children aged less than five and low birth interval (Table 2$)$.

\begin{tabular}{|c|c|c|c|}
\hline Parameters & $\begin{array}{l}\text { Lowland } \# \\
(\mathrm{n}=104)\end{array}$ & $\begin{array}{l}\text { Midland\#\# } \\
\quad(n=98)\end{array}$ & P-Value \\
\hline Age (y) & $28.3 \pm 5.2$ & $28.6 \pm 6.6$ & 0.751 \\
\hline BMI & $19.2 \pm 2.3$ & $18.9 \pm 1.8$ & 0.365 \\
\hline Parity & $4.4 \pm 2.2$ & $4.3 \pm 2.5$ & 0.813 \\
\hline Children $<5 \mathrm{y}$ & $1.8 \pm 0.6$ & $1.5 \pm 0.5$ & $0.000^{* *}$ \\
\hline $\begin{array}{l}\text { Attended antenatal } \\
\text { care }\end{array}$ & $2.7 \pm 1.2$ & $3.8 \pm 1.5$ & $0.000^{* *}$ \\
\hline $\begin{array}{l}\text { Haemoglobin (g/ } \\
\text { dl) }\end{array}$ & $12.9 \pm 2.0$ & $13.4 \pm 0.8$ & $0.023^{* *}$ \\
\hline Serum zinc $(\mu \mathrm{g} / \mathrm{l})$ & $45.0 \pm 14.0$ & $68.8 \pm 24.0$ & $0.000^{* *}$ \\
\hline $\begin{array}{l}\text { Serum ferritin } \\
\qquad(\mu \mathrm{g} / \mathrm{l})\end{array}$ & $26.8 \pm 23.6$ & $80.2 \pm 51.0$ & $0.000^{* *}$ \\
\hline $\begin{array}{l}\text { Median urinary } \\
\text { iodine }(\mu \mathrm{g} / \mathrm{l})\end{array}$ & $122.1 \pm 108.8$ & $118.2 \pm 83.6$ & 0.970 \\
\hline $\begin{array}{c}\text { Family size (total in } \\
\text { home) }\end{array}$ & $5.8 \pm 2.0$ & $5.7 \pm 2.0$ & 0.906 \\
\hline MUAC $(\mathrm{cm})$ & $22.0 \pm 1.6$ & $21.7 \pm 1.4$ & 0.930 \\
\hline $\begin{array}{l}\text { Height of mothers } \\
\qquad(\mathrm{cm})\end{array}$ & $159.7 \pm 5.8$ & $159.2 \pm 5.4$ & 0.597 \\
\hline Birth interval (y) & $2.2 \pm 1.5$ & $2.9 \pm 2.0$ & $0.014^{\star *}$ \\
\hline $\begin{array}{l}\text { Weight of mothers } \\
(\mathrm{kg})\end{array}$ & $49.1 \pm 6.8$ & $48.1 \pm 4.9$ & 0.225 \\
\hline WDDS & $3.0 \pm 1.1$ & $3.1 \pm 0.4$ & 0.767 \\
\hline $\begin{array}{l}\text { Mean duration of } \\
\text { lactation (months) }\end{array}$ & $13.3 \pm 4.4$ & $13.3 \pm 5.3$ & 0.988 \\
\hline
\end{tabular}

\footnotetext{
Values are expressed as mean \pm standard deviation; BMI: Body Mass Index calculated as weight in $\mathrm{kg} / \mathrm{height}$ in meter squared $\left(\mathrm{kg} / \mathrm{m}^{2}\right)$; MUAC: Mid Upper Arm Circumference; WDDS: Women Dietary Diversity Score

${ }^{* *}$ P-Values statistically significant at $\mathrm{P}<0.05$

\#Babile District (Woreda) which is $560 \mathrm{~km}$ away from Addis Ababa in the eastern part of Ethiopia is representing a lowland agro-ecological zone. \#\#Hintalo Wajirat and Endreta districts are $683 \mathrm{~km}$ and $773 \mathrm{~km}$ away from Addis Ababa in the northern part of Ethiopia, respectively and represent midland agro-ecological zones

Table 2: Comparison of maternal characteristics of lactating mothers in two agro-ecological zones of rural Ethiopia $(\mathrm{N}=$ 202)
}

\section{Prevalence of low zinc, iron and iron deficiency anaemia}

The mean serum zinc concentration of the study participants was $57.5 \pm 23.1 \mu \mathrm{g} /$ litre (Table 2) with a low serum level of (serum zinc $<66 \mu \mathrm{g} /$ litre) in 145 participants (71.8\%) (Table 3). Mean serum ferritin (SF) concentration of the participants was $52.7 \pm 4.8$ $\mu \mathrm{g} /$ litre (Table 2). The prevalence of iron deficiency (ID) determined by serum ferritin $(<15 \mu \mathrm{g} / \mathrm{litre}$ ) was $20.8 \%$ (Table 3 ). Iron deficiency anaemia (low haemoglobin + SF) was observed in 22 participants (10.9\%). Among 41 (20.3\%) mothers with zinc and ID in combination, 39 (95.1\%) of them also were from lowland agro-ecological zones (Table 3). 


\begin{tabular}{|c|c|c|c|c|c|}
\hline & Responses & Total n (\%) & Lowland\# n (\%) & Midland\#\# n (\%) & P-value \\
\hline $\begin{array}{l}\text { Iron deficiency } \\
\text { (serum ferritin SF) }\end{array}$ & $\begin{array}{c}\text { Severe }(<15 \mu \mathrm{g} / \mathrm{l}) \\
\text { Normal ferritin value }(>15 \mu \mathrm{g} / \mathrm{l})\end{array}$ & $\begin{array}{c}42(20.8) \\
160(79.2)\end{array}$ & $\begin{array}{l}39(37.5) \\
65(62.5)\end{array}$ & $\begin{array}{c}3(3.1) \\
95(96.9)\end{array}$ & 0.000 \\
\hline IDA (low Hgb +SF) & $\begin{array}{l}\text { Yes } \\
\text { No }\end{array}$ & $\begin{array}{c}22(10.9) \\
180(89.1)\end{array}$ & $\begin{array}{l}21(20.2) \\
83(79.8)\end{array}$ & $\begin{array}{c}1(1) \\
97(99)\end{array}$ & 0.000 \\
\hline $\begin{array}{l}\text { Level of anaemia (hae- } \\
\text { moglobin) }\end{array}$ & $\begin{array}{c}\text { Moderate }(7-9.9 \mathrm{~g} / \mathrm{dl}) \\
\text { Mild }(10-11.9 \mathrm{~g} / \mathrm{dl}) \\
\text { Overall anaemia }(\mathrm{Hgb}<12 \mathrm{~g} / \mathrm{dl}) \\
\text { Non anaemic mothers }\end{array}$ & $\begin{array}{c}5(2.5) \\
37(17.8) \\
42(20.3) \\
160(79.7)\end{array}$ & $\begin{array}{c}5(4.8) \\
30(28.8) \\
35(33.6) \\
69(66.4)\end{array}$ & $\begin{array}{c}0 \\
7(6.1) \\
7(6.1) \\
91(93.9)\end{array}$ & $\begin{array}{c}\text { NA } \\
0.000 \\
0.000\end{array}$ \\
\hline Serum zinc & $\begin{array}{c}<66 \mu \mathrm{g} / 1 \\
>=66 \mu \mathrm{g} / 1\end{array}$ & $\begin{array}{c}145(71.8) \\
57(28.2)\end{array}$ & $\begin{array}{c}100(96.2) \\
4(3.8)\end{array}$ & $\begin{array}{l}45(45.9) \\
53(54.1)\end{array}$ & 0.000 \\
\hline MUAC & $\begin{array}{l}<22 \mathrm{~cm} \\
>22 \mathrm{~cm}\end{array}$ & $\begin{array}{c}84(41.6) \\
118(58.4)\end{array}$ & $\begin{array}{l}51(49.0) \\
53(51.0)\end{array}$ & $\begin{array}{l}33(33.7) \\
65(66.3)\end{array}$ & 0.027 \\
\hline BMI & $\begin{array}{l}<18.5(\mathrm{~kg} / \mathrm{m} 2) \\
>18.5(\mathrm{~kg} / \mathrm{m} 2)\end{array}$ & $\begin{array}{c}85(42.1) \\
117(57.9)\end{array}$ & $\begin{array}{l}42(40.4) \\
61(59.6)\end{array}$ & $\begin{array}{l}43(43.9) \\
56(56.1)\end{array}$ & 0.702 \\
\hline Urinary iodine & $\begin{array}{l}<100 \mu \mathrm{g} / 1 \\
>=100 \mu \mathrm{g} / 1\end{array}$ & $\begin{array}{c}86(42.6) \\
116(57.4)\end{array}$ & $\begin{array}{l}47(45.2) \\
57(54.8)\end{array}$ & $\begin{array}{l}39(39.8) \\
59(60.2)\end{array}$ & 0.440 \\
\hline Salt iodine & $\begin{array}{c}0 \mathrm{ppm} \\
15 \mathrm{ppm} \\
>15 \mathrm{ppm}\end{array}$ & $\begin{array}{c}26(12.9) \\
102(50.5) \\
74(36.6)\end{array}$ & $\begin{array}{l}12(11.5) \\
65(62.5) \\
27(26.0)\end{array}$ & $\begin{array}{l}14(14.3) \\
37(37.7) \\
47(48.0)\end{array}$ & $\begin{array}{l}0.380 \\
0.004\end{array}$ \\
\hline Goitre rate & $\begin{array}{c}\text { Grade } 2 \text { (Visible) } \\
\text { Grade } 1 \text { (Palpable) } \\
\text { Grade } 0 \text { (No goitre) } \\
\text { Total goitre rate (TGR) (visible } \\
\text { + palpable) }\end{array}$ & $\begin{array}{c}5(2.5) \\
66(32.7) \\
131(64.9) \\
71(35.2)\end{array}$ & $\begin{array}{c}4(3.8) \\
34(32.7) \\
66(63.5) \\
38(36.5)\end{array}$ & $\begin{array}{c}1(1) \\
32(32.7) \\
65(66.3) \\
33(33.7)\end{array}$ & $\begin{array}{l}0.190 \\
0.880\end{array}$ \\
\hline $\begin{array}{l}\text { Ferritin and zinc } \\
\text { deficient }^{* *}\end{array}$ & $\begin{array}{l}\text { Yes } \\
\text { No }\end{array}$ & $\begin{array}{c}41(20.0) \\
161(80.0)\end{array}$ & $\begin{array}{l}39(37.5) \\
65(62.5)\end{array}$ & $\begin{array}{c}2(2.0) \\
96(98.0)\end{array}$ & 0.000 \\
\hline
\end{tabular}

BMI: Body Mass Index calculated as weight in $\mathrm{kg} / \mathrm{height}$ in meter squared (kg/m2); MUAC: Mid Upper Arm Circumference; Hgb: Haemoglobin; SF: Serum ferritin; WDDS: Women Dietary Diversity Score

${ }^{* *}$ Ferritin and zinc deficient is defined as mothers with serum ferritin less than $15 \mu \mathrm{g} / \mathrm{l}$ and zinc level less than $66 \square \mathrm{g} / \mathrm{l}$

\#Babile District (Woreda) which is $560 \mathrm{~km}$ away from Addis Ababa in the eastern part of Ethiopia is representing a lowland agroecological zone. \#\#HintaloWajirat and Endreta districts are $683 \mathrm{~km}$ and $773 \mathrm{~km}$ away from Addis Ababa in the northern part of Ethiopia, respectively and represent midland agro-ecological zones

Table 3: Prevalence of micronutrient deficiency and malnutrition among lactating mothers in two agro-ecological zones of rural Ethiopia $(\mathrm{N}=202)$

\section{Prevalence of iodized salt utilization and Total Goitre Rate}

Adequate iodized salt (with $>15 \mathrm{ppm}$ ) was found in $36.6 \%$ of the households (Table 3), about half (50.5\%) of households have salt with less than $15 \mathrm{ppm}$ and the remaining households (12.9\%) use non-iodized salt. The median Urinary Iodine Concentration (UIC) of lactating mothers was $120 \mu \mathrm{g} /$ litre, and $42.6 \%$ of the mothers had UIC less than $100 \mu \mathrm{g} /$ litre (Table 3). The weighted total goitre (TGR) rate among lactating mothers in this study group was 35.2\% (95\%, CI = 28.6 - 42.1), 32.7\% palpable and 2.5\% visible goitre (Table 3).

\section{Prevalence of low serum zinc, iron and urinary iodine by agro-ecological zone}

The proportion of lactating mothers with zinc, iron deficiency and iron deficiency anaemia was considerably higher among lowland residents compared to midland (Table 3). Greater than $96 \%$ of mothers in the lowland region had serum zinc levels less than $66 \mu \mathrm{g} /$ litre. On the other hand, about $46 \%$ of mothers had zinc level below this cut-off in the midland zone. Higher prevalence of ID (serum ferritin levels $<15 \square \mathrm{g}$ /litre) was observed among lowland agro-ecological zones (37.5\% versus $3.1 \%$ in midland) (Table 3). The levels of anaemia in the two zones paralleled the ID rates. Overall levels of ID in this study population, as assessed by serum ferritin concentration, were very high. Nearly $21 \%$ of surveyed mothers had serum ferritin concentrations less than 15 $\mu \mathrm{g} /$ litre which is an indicator of ID (Table 3).

The prevalence of Total Goitre Rate (TGR) was very similar in both zones with slightly higher incidence in the lowland (36.5\%) agro-ecological zone compared to the midland (33.7\%). The number of mothers with visible goitre was 4 in the lowland and 1 individual in midland region (Table 3 ).

About 20\% of mothers surveyed were deficient in both biomarkers (zinc and iron) with higher rate (37.5\%) in the lowland zone while only $2.0 \%$ of mothers in the midland zone were deficient in both biomarkers measured in this study (Table 3 ).

Table 4 shows the correlation between micronutrient status, malnutrition and dietary diversity scores among lactating mothers in rural Ethiopia. Maternal serum ferritin concentration levels were significantly associated with serum zinc $(r=0.374, p=0.000)$ and haemoglobin level $(r=0.21, p=0.003)$. Haemoglobin levels were associated with maternal BMI $(r=0.165, p=0.019), M U A C$ 
$(\mathrm{r}=0.175, \mathrm{p}=0.013)$ and Women Dietary Diversity Score $(\mathrm{r}=0.192, \mathrm{p}=0.006)$ in addition to serum ferritin. Maternal MUAC was positively associated with maternal BMI $(r=0.619, \mathrm{p}=0.000)$ in addition to haemoglobin levels. Maternal age was negatively but not significantly associated with concentrations of zinc, ferritin and haemoglobin. As the age of the mother increased, maternal BMI tended to increase also.

\begin{tabular}{|c|l|c|c|c|c|c|c|}
\hline Variables & & Ferritin & Zinc & Haemo-globin & BMI & MUAC & WDDS \\
\hline \multirow{2}{*}{ Ferritin } & $\begin{array}{c}\text { P. Correlation } \\
\text { Sig. (2-tailed) }\end{array}$ & 1.00 & & & & & \\
& & & & & & \\
\hline \multirow{2}{*}{ Zinc } & P. Correlation & $0.374^{* *}$ & 1.00 & & & & \\
& Sig. (2-tailed) & $<0.001$ & & & & & \\
\hline \multirow{2}{*}{ Haemoglobin } & P. Correlation & $0.211^{* *}$ & 0.096 & 1.00 & & & \\
& Sig. (2-tailed) & 0.003 & 0.173 & & & & \\
\hline \multirow{2}{*}{ BMI } & P. Correlation & -0.075 & $-0.146^{*}$ & $0.165^{*}$ & 1.00 & & \\
& Sig. (2-tailed) & 0.291 & 0.039 & 0.019 & & & \\
\hline \multirow{2}{*}{ MUAC } & P. Correlation & -0.078 & -0.074 & $0.175^{*}$ & $.619^{* *}$ & 1.00 & \\
& Sig. (2-tailed) & 0.270 & 0.295 & 0.013 & $<0.001$ & & \\
\hline \multirow{2}{*}{ WDDS } & P. Correlation & 0.093 & 0.104 & $0.192^{* *}$ & -0.034 & -0.030 & 1.0 \\
& Sig. (2-tailed) & 0.189 & 0.139 & 0.006 & 0.627 & 0.668 & \\
\hline \multirow{2}{*}{$\begin{array}{c}\text { Age of the } \\
\text { mothers }\end{array}$} & P. Correlation & -0.052 & -0.025 & -0.061 & 0.25 & 0.10 & -0.01 \\
& Sig. (2-tailed) & 0.46 & 0.72 & 0.39 & $<0.001$ & 0.145 & 0.87 \\
\hline
\end{tabular}

P: Pearson correlation; BMI: Body Mass Index calculated as weight in kg/height in meter (kg/m²); MUAC: Mid Upper Arm Circumference; WDDS: Women Dietary Diversity Score

${ }^{*}$ Correlation is significant at the 0.05 level (2-tailed)

${ }^{*}$ Correlation is significant at the 0.01 level (2-tailed)

Table 4: Correlation between micronutrients, malnutrition and Women Dietary Diversity Score among lactating mothers in rural Ethiopia $(\mathrm{N}=202)$

\section{Discussion}

This study conducted in lactating mothers confirmed that $71.8 \%$ had low serum zinc, $60.4 \%$ had low iron status and $42.6 \%$ of the mothers had UIC less than $100 \mu \mathrm{g} / \mathrm{L}$. Of the mothers with low iron status, $10.9 \%$ had IDA. The deficiencies were more pronounced in lowland (96.2\% for zinc and 89.4\% for iron) compared to midland (45.9\% for zinc and 29.6\% for iron) agro-ecological zones.

Our observation of zinc deficiency of $71.8 \%$ is similar to that reported in pregnant women in Ethiopia at 74\% [31]. The higher prevalence of low serum zinc found in the present study could be due to an inadequate zinc intake and/or poor bioavailability. It is worthy to note that several dietary factors are known to affect zinc absorption as a result of physico-chemical interactions in the intestine. Phytate, a component in plants with the highest concentration found in seeds (cereal grains/legumes/nuts), inhibits zinc absorption [32]. This might hold true in the subjects of the present study, as cereal is a staple food in both agro-ecological zones. Additionally, good sources of bioavailable zinc, like meat and egg, were poorly consumed especially in the lowland agro-ecological zone.

On the basis of the WHO cut-off points for serum ferritin [23], the prevalence of iron deficiency in the present study population was $20.8 \%$. When we compare prevalence of iron deficiency among agro-ecological zones, an exceptionally higher prevalence was recorded among lowland community (37.5\% versus $3.1 \%$ ). This prevalence is larger than reported in other studies conducted in Ethiopia [16,33].

The WDDS was similar but low in both agro-ecological zones (Table 2). Evidence for a close association between dietary diversity and micronutrient deficiencies in developing countries is well documented $[34,35]$. Some cereal crops, notably teff the main cereal consumed in the midland agro-ecological zone, are high in iron and fermented enset may increase non-heme iron absorption. Additionally, a marked observation in the present study is the lower intakes of meat (source of heme iron) and eggs among mothers from the lowland zone (Table 1). Heme iron from animal foods is much better absorbed than non-heme iron from plant source food where iron absorption may range from as low as 1 to $10 \%$. A striking difference was noted for legume consumption among the study participants between the two agro-ecological zones. Ninety nine percent of mothers in the midland zone reported consuming legumes the day prior to the study while only $43.3 \%$ of mothers in the lowland zone consumed these foods. Legumes are a rich source of vitamin $\mathrm{C}$ and this could be another factor related to the differences in iron deficiency anaemia between the two zones. Frequent consumption of coffee and tea was observed. Consumption of these beverages was much higher in the lowland zone. Coffee and tea contain phenolic compounds that inhibit the absorption of iron. In addition to their appetitesuppressing effects, these beverages are of low nutrient density, thus when consumed especially with sugar, they may displace more nutritious foods.

Women frequently enter pregnancy with insufficient nutrient stores, and the increased demands associated with pregnancy and lactation are reported to increase risk of developing anaemia [36]. Our data show that antenatal care and birth interval were greater in the midland agro-ecological zone compared to lowland. These factors could also be contributing to the differences in anaemia rates between the two zones. On the other hand, no differences in parity and family size were seen between the zones. 
Although the presence of parasitic infections, particularly hookworm, is associated with bleeding and hence higher levels of iron deficiency, this did not appear to contribute significantly to the differences in iron deficiency between the lowland and midland zones in the present study. There was no significant difference between the lowland and midland zones with respect to the practice of taking deworming tablets, households with toilet, hand washing practices and mother being sick in past 15 days. Thus, our findings suggest that difference in iron deficiency between the two agro-ecological zones is mainly caused by dietary factors. Additionally, we have previously reported variations in dietary diversity and traditional feeding habits between these two agroecological zones in rural Ethiopia [37].

The $10.9 \%$ prevalence of IDA in the present study is lower than reported for lactating mothers in an urban slum of Addis Ababa (22\%) [17], non-pregnant Ethiopian women [16], and similar to the figure (13\%) reported in pregnant mothers in southern Ethiopia [31]. Prevalence of IDA was higher in the lowland agro-ecological zone (37.5\%) compared to lactating mothers from Addis Ababa (22\%) [17]. These differences are again most likely to be related to variations in dietary pattern in the different zones of rural Ethiopia [16].

This study also demonstrated that deficiencies of zinc and iron occur concurrently. Once again, prevalences were higher in the lowland agro-ecological zone. The coexistence of zinc and iron deficiencies is probably related to high intakes of cereal which is rich in phytate and very low intakes of animal proteins [32,37]. In addition to dietary factors, mothers living in less developed countries, like Ethiopia, are exposed to frequent diarrhoea and respiratory infections, recurrent pregnancy and prolonged lactation all of which can influence micronutrient status [38].

Among the participants, $20 \%$ mothers were deficient in both zinc and iron. This prevalence is greater than reported in studies in Gondar [14]. Our data indicate that the majority of the mothers in the study area are affected by at least a single micronutrient deficiency, with the coexistence of micronutrient deficiencies most likely due to common aetiology and underlying mechanisms. For instance, a diet rich in phytate and low in animal proteins is common in most developing countries including Ethiopia; such a dietary pattern predisposes individuals to insufficient intake and absorption of zinc and iron [39,40].

This study showed that ferritin level is positively and significantly correlated with haemoglobin and zinc. As the level of ferritin increases, the serum levels of haemoglobin and zinc will also increase. The associations between zinc, iron and anaemia were reported in others studies $[41,42]$. Likewise haemoglobin levels were significantly correlated with maternal BMI, MUAC and WDDS which suggests that intervention directed to alleviate micronutrient deficiencies should be multidimensional.

The prevalence of goitre observed among lactating mothers in this study (35.2\%) is similar to that reported in other studies among reproductive age Ethiopian women [19,43]. Our data are in accord with previous work in Ethiopia [19] which reported $>30 \%$ TGR in Tigray, Oromia, the Southern Nations, and Beshangul-Gumuz. According to WHO/UNICEF/ICCIDD [29], a total goitre rate of $5 \%$ is a cut-off point indicating a public health risk of adverse functional consequences and when TGR is higher than $30 \%$ the problem is severe. The percentage of lactating mothers with UIC less than $100 \mu \mathrm{g} / \mathrm{L}$ was $42.6 \%$. However, even higher prevalences have been reported in Papua New Guinea, 60\% [44] and Niger, 69.7\% [45]. WHO/UNICEF/ICCIDD recommended cut-off point of $<100 \mu \mathrm{g} / \mathrm{L}$ for urinary iodine concentration (UIC) is for population groups [29]. This cut-off point is a good indicator of iodine status in populations but there is no good established urinary biomarker for iodine status of individuals. UIC is associated with high intra- and inter-individual variation and hence the determination of UIC in a single spot sample should not ideally be used to categorise an individual. Konig, et al. (2011) presented data indicating that 10 spot urine samples were needed to assess individual iodine status with $20 \%$ precision [46]. These authors noted the major limitation of this large number of repeated urine samples needed to estimate individual iodine status. This is particularly the case with respect to our study conducted in rural zones in Ethiopia. Thus, our findings and inferences with respect to UIC need to be evaluated in light of this limitation. High prevalence of suboptimal status of iodine nutrition among lactating mothers is of concern because of the association between subclinical iodine deficiency in lactating mothers and the potential risk of abnormal brain development in breastfed infants. The breast feeding mother provides the nursing infant with its sole source of iodine while the infant is exclusively breastfed $[47,48]$.

Iodized salt was found in $36.6 \%$ of the households in our study which is greater than that reported in other studies conducted elsewhere in Ethiopia [43,48,49]. However, the Ethiopian government has set up a Universal Salt Iodization program even though there is a lot more to do to achieve WHO/UNICEF guidelines [47].

A limitation of this study is that although bloods were collected from apparently healthy individuals, acute phase proteins, including C-reactive protein (CRP), tests were not conducted due to financial reasons and absence of reagents at national level during this study period. Due to shortage of budget, some more micronutrients, like serum Vitamin A and copper were not examined. As data were collected by interview, social desirability bias could not be totally excluded.

\section{Conclusions}

In summary, the results of the present study reveal a high magnitude of micronutrient deficiencies, independently as well as concurrently, among lactating mothers in both agro-ecological zones. However, the deficiencies were more pronounced in lowland compared to midland agro-ecological zone of rural Ethiopia. These data suggest the need to undertake agro-ecological based studies in various parts of Ethiopia to determine appropriate interventions in all reproductive age mothers. Increased animal food consumption and increased consumption of vegetables and fruits is recommended in this population group. 


\section{Acknowledgements}

Kedir Teji would like to acknowledge the entire AGRIDIET principal investigators and team for their great guidance, assistance and support during his stay in Cork. Our appreciation also goes to Haramaya University for assisting us in transport facilities during the data collection. We also thank the Ethiopian Public Health Institute for analysing the micronutrients and Hiwot Fana Specialized University Hospital for separating serum from whole blood and storing the serum at the required temperature. Also, Kedir Teji wishes to express his sincere gratitude to all participants of the study, his family, and data collectors.

\section{References}

1. Black RE, Victora CG, Walker SP, Bhutta ZA, Christian P, et al. (2013) Maternal and child undernutrition and overweight in low-income and middle-income countries. Lancet 382: 427-51.

2.World Health Organization (2015) Micronutrient deficiencies - Iron deficiency anaemia. Geneva: WHO.

3. Andersson M, Karumbunathan V, Zimmermann MB (2012) Global iodine status in 2011 and trends over the past decade. J Nutr 142: 744-50.

4. King JC (2011) Zinc: an essential but elusive nutrient. Am J Clin Nutr 94: 679S-84S.

5. Wessells KR, Brown KH (2012) Estimating the global prevalence of zinc deficiency: results based on zinc availability in National Food Supplies and the prevalence of stunting. PLoS One 7: e50568. doi: 10.1371/journal.pone.0050568.

6. Institute of Medicine, Food and Nutrition Board (2001) Dietary Reference Intakes for Vitamin A, Vitamin K, Arsenic, Boron, Chromium, Copper, Iodine, Iron, Manganese, Molybdenum, Nickel, Silicon, Vanadium and Zinc. Washington, DC. National Academy Press.

7. Camaschella C (2015) Iron-deficiency anemia. N Engl J Med 372: 1832-43.

8. Milman N (2011) Anemia - still a major health problem in many parts of the world!. Ann Hematol 90: 369-77.

9. Kent JC (2007) How breastfeeding works. J Midwifery Womens' Health 52: 564-70.

10. Demissie T, Mekonen Y, Haider J (2003) Agro-ecological comparison levels and correlate of nutritional status of women. Ethiop J Health Dev 17: 189-96.

11. Zhao A, Zhang Y, Li B, Wang P, Li J, et al. (2014) Prevalence of anemia and its risk factors among lactating mothers in Myanmar. Am J Trop Med Hyg 90: 963-7.

12. A2Z, FANTA project (2006) Maternal anemia: A preventable killer.

13. Kalaivani K (2009) Prevalence \& consequences of anaemia in pregnancy. Indian J Med Res 130: 627-33.

14. Kassu A, Yabutani T, Mulu A, Tessema B, Ota F (2008) Serum zinc, copper, selenium, calcium, and magnesium levels in pregnant and non-pregnant women in Gondar, Northwest Ethiopia. HIV Biol Trace Elem Res 122: 97-106.

15. Gebremedhin S, Enquselassie F, Umeta M (2011) Prevalence of prenatal zinc deficiency and its association with socio-demographic, dietary and health care related factors in Rural Sidama, Southern Ethiopia: A crosssectional study. BMC Public Health 11: 898 doi: 10.1186/1471-2458-11-898.

16. Umeta M, Haidar J, Demissie T, Akalu G, Ayana G (2008) Iron deficiency anaemia among women of reproductive age in nine administrative regions of Ethiopia. Ethiop J Health Dev 22: 252-8.

17. Haidar J, Muroki NM, Omwega AM, Ayana G (2003) Malnutrition and iron deficiency in lactating women in urban slum communities from Addis Ababa, Ethiopia. East Afric Med J 80: 191-4.

18. Kedir H, Berhane Y, Worku A (2014) Subclinical iodine deficiency among pregnant women in Haramaya District, Eastern Ethiopia: A community-based study. J Nutr Metabol doi: 10.1155/2014/878926.

19. Abuye C, Berhane Y (2007) The goitre rate, its association with reproductive failure, and the knowledge of iodine deficiency disorders (IDD) among women in Ethiopia: cross-section community based study. BMC Public Health 7: 316.

20. Cogill B (2001) Anthropometric indicators measurement guide. Food and Nutrition Technical Assistance, (FANTA). Academy for Educational Development (AED), Washington, DC.

21. Swindale A, Bilinsky P (2006) Household dietary diversity score (HDDS) for measurement of household food access: indicator guide, Version 2. Food and Nutrition Technical Assistance, (FANTA). Academy for Educational Development (AED), Washington, DC.

22. IZiNCG (2007) Assessment of the risk of zinc deficiency in populations and options for its control.

23. World Health Organisation (2001) Iron deficiency anaemia: assessment, prevention and control, a guide for programme managers. Geneva: WHO.

24. Nkrumah B, Nguah S, Sarpong N, Dekker D, Idriss A, et al. (2011) Hemoglobin estimation by the HemoCueH portable hemoglobin photometer in a resource poor setting. BMC Clin Pathol 11: 5 .

25. World Health Organisation (2011) Haemoglobin concentrations for the diagnosis of anaemia and assessment of severity. Vitamin and Mineral Nutrition Information System. Geneva: WHO.

26. Iyengar GV, Subramanian KS, Woittiez JRW (1998) Element analysis of biological samples: Principles and Practice. CRC Press, Boca Raton, FL.

27. Peaston RT (1973) Determination of copper and zinc in plasma and urine by atomic absorption spectrophotometry. Med Lab Technol 30: $249-53$.

28. Gnat D, Dunn AD, Chaker S, Delange F, Vertongen F, et al. (2003) Fast colorimetric method for measuring urinary iodine Clin Chem 49: 186-8.

29. World Health Organisation (2013) Urinary iodine concentrations for determining iodine status deficiency in populations. Vitamin and Mineral Nutrition Information System. Geneva: WHO.

30. World Health Organisation (2007) Assessment of iodine deficiency disorders and monitoring their elimination: A guide for program managers, $3^{\text {rd }}$ ed., Geneva: WHO.

31. Gibson RS, Abebe Y, Stabler S, Allen RH, Westcott JE, et al. (2008) Zinc, gravida, infection and iron, but not vitamin B-12 or folate status, predict hemoglobin during pregnancy in Southern Ethiopia. J Nutr 138: 581-6.

32. Miller LV, Krebs NF, Hambidge KM (2007) A mathematical model of zinc absorption in humans as a function of dietary zinc and phytate. J Nutr 137: 135-41. 
33. Haidar JA, Pobocik RS (2009) Iron deficiency anemia is not a rare problem among women of reproductive ages in Ethiopia: a community based cross sectional study. BMC Blood Disorders 9: 7.

34. Arsenault JE, Yakes EA, Islam MM, Hossain MB, Ahmed T, et al. (2013) Very low adequacy of micronutrient intakes by young children and women in rural Bangladesh is primarily explained by low food intake and limited diversity. J Nutr 143: 197-203.

35. Henjum S, Torheim LE, Thorne-Lyman AL, Chandyo R, Fawzi WW, et al. (2015) Low dietary diversity and micronutrient adequacy among lactating women in a peri-urban area of Nepal. Public Health Nutr doi: 10.1017/S1368980015000671.

36. Van den Broek N (2003) Anaemia and micronutrient deficiencies. Br Med Bull 67: 149-60.

37. Roba KT, O'Connor TP, Belachew T, O’Brien NM (2015) Seasonal variation in nutritional status and anaemia among lactating mothers in two agro-ecological zones of rural Ethiopia: A longitudinal study. Nutrition 31: 1213-8.

38. Mason JB, Saldanha LS, Ramakrishnan U, Lowe A, Noznesky EA, et al. (2012) Opportunities for improving maternal nutrition and birth outcomes: synthesis of country experiences. Food Nutr Bull 33: S104-37.

39. Gibson RS (2012) A historical review of progress in the assessment of dietary zinc intake as an indicator of population zinc status. Adv Nutr 3: $772-82$.

40. Pasricha SR, Drakesmith H, Black J, Hipgrave D, Biggs BA (2013) Control of iron deficiency anemia in low- and middle-income countries. Blood 121: 2607-17.

41. Stuetz W, Carrara VI, McGready R, Lee SJ, Erhardt JG, et al. (2012) Micronutrient status in lactating mothers before and after introduction of fortified flour: cross-sectional surveys in Maela refugee camp. Eur J Nutr 51: 425-34.

42. Cole CR, Grant FK, Swaby-Ellis ED, Smith JL, Jacques A, et al. (2010) Zinc and iron deficiency and their interrelations in low-income African American and Hispanic children in Atlanta. Am J Clin Nutr 91: 1027-34

43. Aweke KA, Adamu BT, Girmay AM, Yohannes T, Alemnesh Z, et al. (2014) Iodine deficiency disorders in Burie and Womberma districts, West Gojjam, Ethiopia. Afric J Food Agric Nutr Develop 14: 9167-87.

44. Temple VJ, Oge R, Daphne I, Vince JD, Ripa P, et al. (2009) Salt iodization and iodine status among infants and lactating mothers in Papua New Guinea. Afric J Food Agric Nutr Develop 9: 1807-23.

45. Sadou H, Moussa Y, Alma MM, Daouda H (2013) Iodine status of breastfed infants and their mothers after sixteen years of Universal Dietary Salt Iodization Program in Dosso, Niger. Nutr J 7: 7-12.

46. Konig F, Andersson M, Hotz K, Aeberli I, Zimmermann MB (2011) Ten Repeat Collections for Urinary Iodine from Spot Samples or 24-Hour Samples Are Needed to Reliably Estimate Individual Iodine Status in Women. J Nutr 141: 2049-54.

47. World Health Organization (2007) Reaching optimal iodine nutrition in pregnant and lactating women and young children. United Nations Children's Fund Joint statement by WHO and UNICEF Geneva: WHO.

48. WHO Secretariat, Andersson M, de Benoist B, Delange F, Zupan J (2007) Prevention and control of iodine deficiency in pregnant and lactating women and in children less than 2-years-old: conclusions and recommendations of the Technical Consultation. Public Health Nutr 10: 1606-11.

49. Central Statistical Agency [Ethopia] and ICF International (2012) Ethiopia Demographic and Health Survey 2011. Addis Ababa, Ethiopia and Calverton, MD: CSA and ICF International. 